DOI: https://doi.org/10.47405/mjssh.v6i10.1071

\begin{tabular}{|c|c|}
\hline 4 & Malaysian Journal of Social Sciences and Humanities (MJSSH) \\
\hline $\begin{array}{l}\text { Malaysian Juoural of } \\
\text { Social ccciecces and }\end{array}$ & Volume 6, Issue 10, October 2021 \\
\hline (MJ-sSH) & e-ISSN : 2504-8562 \\
\hline & $\begin{array}{l}\text { Journal home page: } \\
\text { www.msocialsciences.com }\end{array}$ \\
\hline
\end{tabular}

\title{
COVID-19 Pandemic and Its Effects on Youth Mental Health in Bangladesh
}

\author{
Mehjabin Haque1, Israt Eshita Haque'2, Md. Noor-e Alam Ziku', Naim Ahamed ${ }^{3}$, Md. Sabbir Hossain ${ }^{4}$ \\ 1University of Dhaka, Dhaka, Bangladesh \\ 2Department of Sociology, Noakhali Science and Technology University, Noakhali-3814, Bangladesh \\ ${ }^{3} \mathrm{NGO}$ Forum for Public Health, Bangladesh \\ ${ }^{4}$ Department of Forestry and Environmental Science, Shahjalal University of Science and Technology, Sylhet-3114, \\ Bangladesh
}

Correspondence: Israt Eshita Haque (eshita.soc@nstu.edu.bd)

\begin{abstract}
COVID-19 is a worldwide pandemic that is caused by severe acute respiratory syndrome coronavirus (SAR-CoV-2). For the effect of this pandemic, the people of Bangladesh are suffering from unprecedented challenges of all ages. Coronavirus pandemic has hit the young mental health badly. The main purpose of this research was to investigate the mental health condition among young people during the COVID-19 pandemic in Bangladesh. In this study, a qualitative research method was used where twenty case studies were carried out to evaluate critical situations as well as the determinants of psychological health problems that young adults are facing. Result demonstrates that like other ages, young people are bound to stay at home during lockdown that causes a profound effect on their mental health. Due to COVID-19 young people are going through a variety of critical situations including financial hardship, conflict with family members, quarantine-related crisis, increasing pressure for marriage, extreme addiction to the virtual world, and addiction to different video games that threaten their psychological health, for example increasing suicidal tendency, loneliness, anxiety, depression, psychological trauma, low self-confidence anger, etc. Researchers have suggested some potential recommendations to reduce the psychological pressure of young people during pandemics.
\end{abstract}

Keywords: COVID-19, pandemic, young people, mental health

\section{Introduction}

Corona Diseases first appeared in Wuhan, Hubei Province, China in November 2019 and after that, it was spreading all over the country of the world (Zhou, et al., 2020). According to the World Health Organization COVID-19 was considered a pandemic from 11 of March 2020. There are three phases of epidemic infections with different psychological reactions (Figure 1).

As we know that epidemiological studies of the effects of pesticides on humans deal with the incidence, distribution, and control of diseases. According to epidemiological measures, there are three phases of pandemic infections with a variety of psychological reactions. In the period of the first phase named the preparation phase, the government imposed to obey social distance and concern general hygiene of common people by taking several policies for not spreading of the infection. Then, the second phase known as the punctum maximum phase is the curve that reaches the upper level in where mortality and new cases increase in a significant number. The return to normality or third phase 
indicates to recovery from a pandemic that is required re-establishing services and practices (Fegert, Vitiello, Plener, \& Clemens, 2020).

Figure 1: Three phases of the pandemic

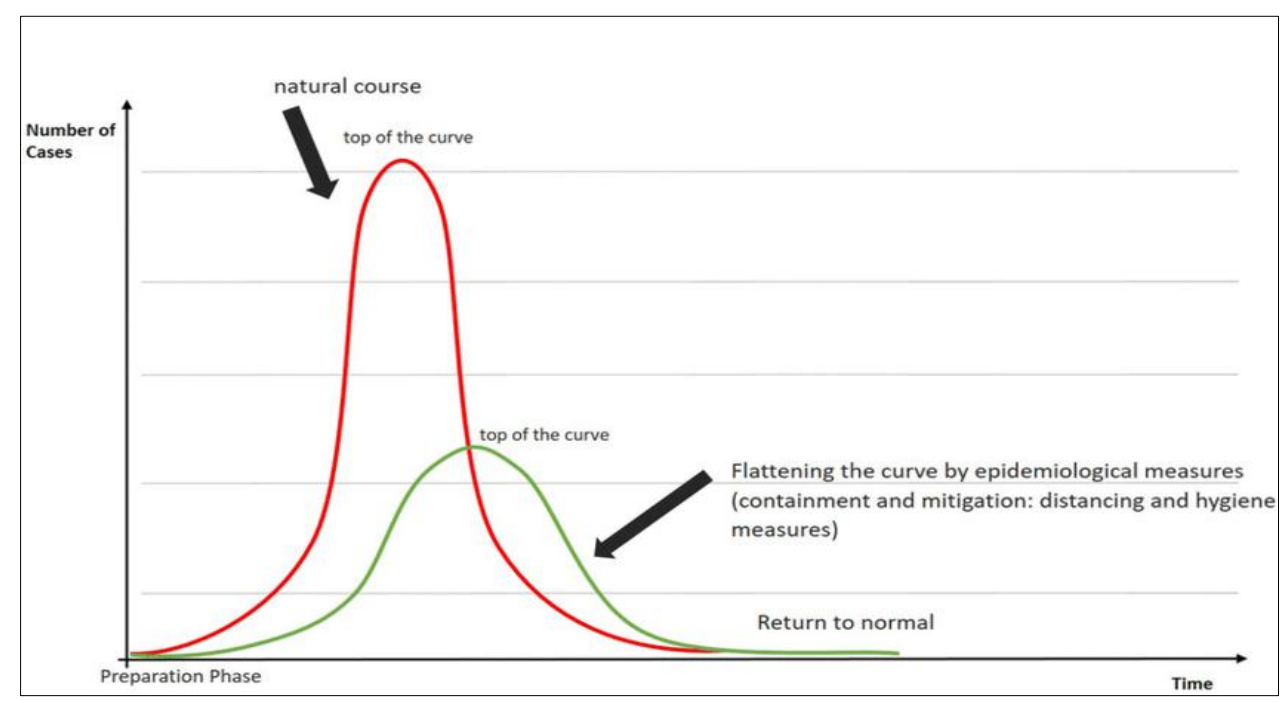

Source: Fegert, Vitiello, Plener, \& Clemens (2020)

In Bangladesh, Government has imposed to obey social distance and made some restrictions as well as suggestive proposals for general people to prevent the spreading of the infection. From the pandemic time, people started getting acquainted with new concepts such as isolation, quarantine, contact restriction, lockdown, and so on. Not only that, schools, colleges, and Universities are also closed from March 2020. Common people are not allowed to go outside without essential work, and all the traveling for recreation has been canceled. As a result, psychological disorders are arising among all ages in where depression and anxiety are very common disorders at young ages (Courtney, Watson, Battaglia, Mulsant, \& Szatmari, 2020).

Despite the various policies of the government, the number of deaths and infection rates is increasing. Due to COVID-19, not only the physical health of people is suffering but also psychological health seems to be affected in an extreme way which is not being noticed sufficiently. During the pandemic situations, young people all over the country of the world are facing a current crisis with anxiety and depressive symptoms (Fegert, Vitiello, Plener, \& Clemens, 2020). The psychological health issue is the major impediment for young ages in their academic success. For the long-lasting pandemic situation young people are bound to stay home which brings negative impact on their mental health that can affect their interaction capability with people, motivation to be social being or other sociocultural participation and concentration on their study (Son, Hegde, Smith, Wang, \& Sasangohar, 2020). Unfortunately, young people's mental health is not being considered a critical issue; although, it should be.

In Bangladesh, up to now, 25,729 people have died due to the coronavirus and 1,482,628 people have been infected by COVID-19 (Worldometer, 2021). Although the death rate in Bangladesh is lower than in any other country in the world, the alarming news is that for the last couple of months, it is increasing terribly. Considering all things, the government has not yet decided to open educational institutions to which young ages are closely connected. There are several studies where assessed mental health issues during the period of the pandemic, but most of the studies have focused on health workers, patients, children, aged people, and general people. The mental condition of the young is deteriorating day by day in Bangladesh (Aresfin \& Shafiullah, 2020). However, there have not been enough studies about mental health at young ages. The main objective of this research is to investigate the relationship between the COVID-19 pandemic with its effect on youth mental health in Bangladesh. The study tries to find out the critical situations faced by young adults during this pandemic by representing the socio-economic condition of the respondents. Therefore, the researchers 
intend to evaluate whether young ages suffer psychological problems due to facing these critical situations in the time of the pandemic as well as give further recommendations of ways for returning to normality.

\section{Methodology}

Due to its subject nature, a qualitative method was applied for this study. Multiple case studies were conducted to do in-depth investigations where a total of twenty students expressed their mental health conditions during COVID-19. Among the ten were male and ten were female students which were selected purposively. All the respondents are students of well-known educational institutions and due to lockdown in Bangladesh, from the middle of March 2020; they come to their homes from their hall or dormitory. The study area of this research is Jamalpur Sadar which is the part of Mymensingh division. It was established in 1978 which is located between $24^{\circ} 34^{\prime}$ and $25^{\circ} 26^{\prime}$ north and between $89^{\circ} 40^{\prime}$ and $90^{\circ} 12^{\prime}$ east.

Figure 2: Map of Jamalpur Sadar

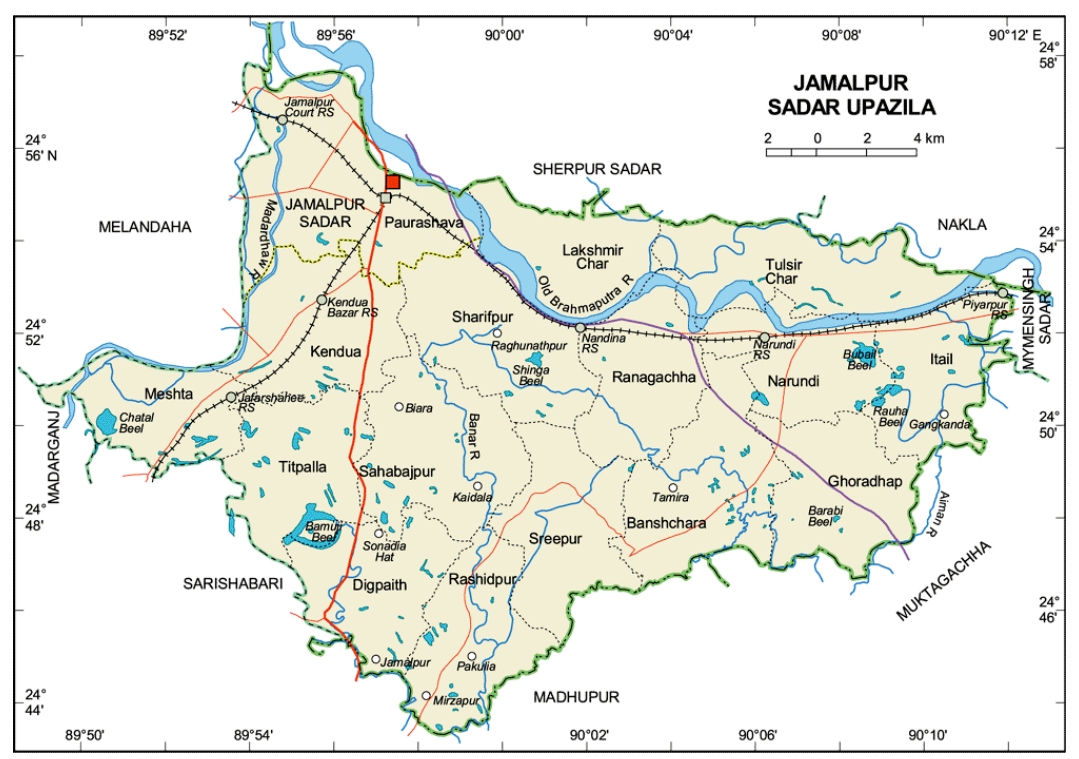

Source: Maps \& Travel information of Bangladesh

Through the interview, researchers gathered a variety of mental health-related information that was occurring in their everyday life in the time of COVID-19. After conducting interviews, researchers transcribed these verbatim to understand the real theme of the respondent's information and experiences. The researchers summarized the transcribed data by using condensation and categorized those into a different theme. To gather data, researchers also used secondary sources like articles, journals, reports, books, websites and, dissertations etcetera (Haque, Haque, \& Muniruzzaman, 2020). After collecting all the data from primary and secondary sources, researchers interpreted the result by working out the implications of the collected data, after that reported the research findings. There is needed to include that, researchers took into account ethical considerations, especially confidentiality in their details and controversial information, throughout the initial research process.

\section{Conceptual Framework and Theoretical Relevance of the Study}

Young people in Bangladesh who have been living at home for a long time may affect their mental health. This study investigates whether young ages are affected by COVID-19 psychologically and socially. The following conceptual framework represents that due to the COVID-19 pandemic young ages in Bangladesh is going through some conditions including financial hardship, conflict with a family member, quarantine-related crisis, increasing the pressure of marriage, addiction to the virtual 
DOI: https://doi.org/10.47405/mjssh.v6i10.1071

world, and so on. Moreover, all these situations influence their mental health in various ways; suicidal tendency, loneliness, anxiety, depression, low self-confidence, etc. are common effects among young ages during the COVID-19 pandemic.

Figure 3: Conceptual Framework of the study

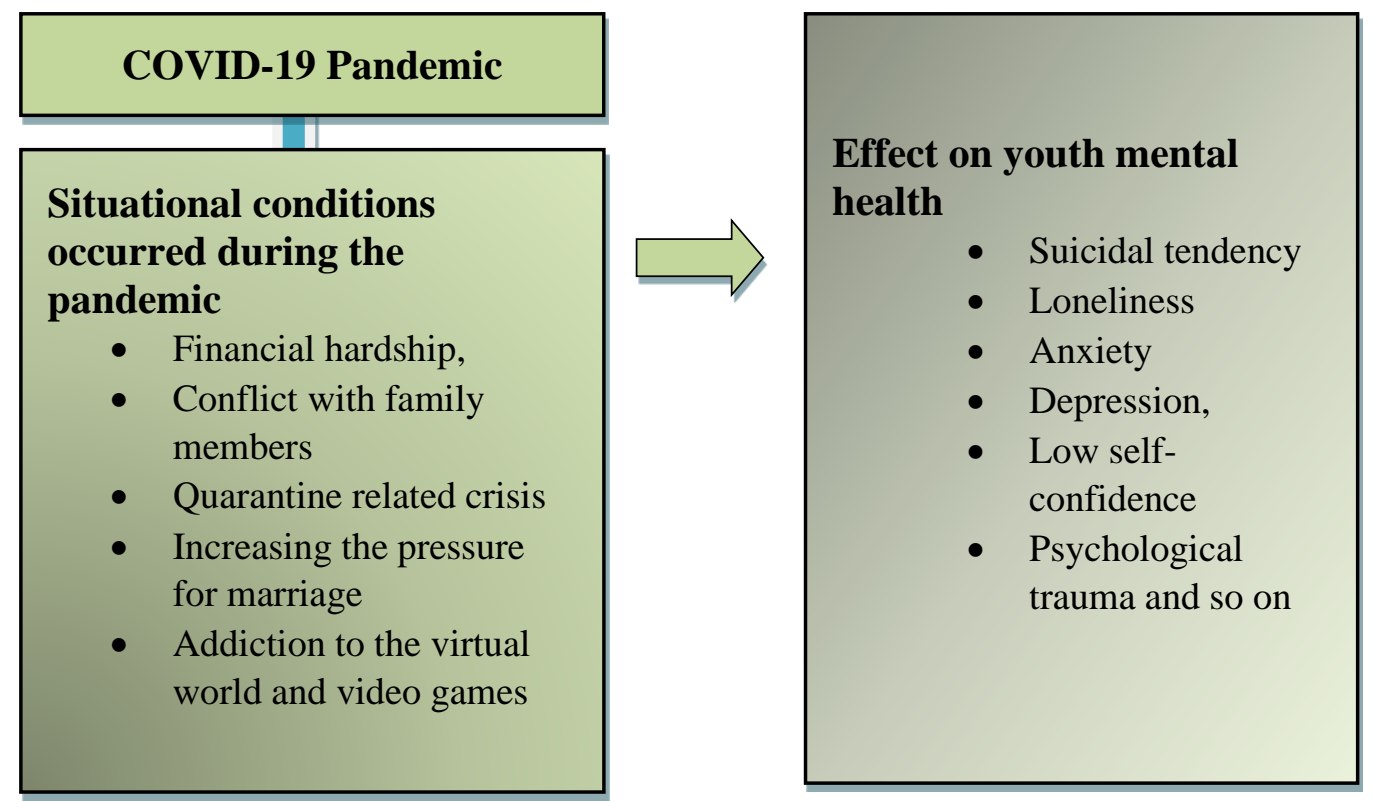

The above conceptual framework shows that whether young people who have been taken as a sample of this study and are suffering from mental health problems due to some situational conditions during the pandemic. Some pioneers developed theories related to this issue. Theoretical relevance has been summarized in the following table:

Table-1: Summary of Theoretical Arguments Based on Mental Health during Pandemic Situation

\begin{tabular}{|c|c|c|}
\hline Theory & Arguments & $\begin{array}{l}\text { Components during the period } \\
\text { of pandemic }\end{array}$ \\
\hline $\begin{array}{l}\text { Social Stress Theory } \\
\text { (Rubinstein \& H, A } \\
\text { Stress-Diathesis Theory } \\
\text { of Suicide, 1986) }\end{array}$ & $\begin{array}{l}\text { A perceived deficiency in social } \\
\text { integration }\end{array}$ & $\begin{array}{l}\text { Individualism, } \\
\text { Loneliness, } \\
\text { Perceived competition for } \\
\text { survival. }\end{array}$ \\
\hline $\begin{array}{l}\text { Biological Theories } \\
\text { (deCatanzaro, 1980) }\end{array}$ & $\begin{array}{l}\text { Social exclusion triggers } \\
\text { Hypothalamic- Pituitary- Adrenal } \\
\text { (HPA axis or HTPA axis) and } \\
\text { Inflammation. Inflammation has a } \\
\text { mutual relationship with } \\
\text { pathogenesis }\end{array}$ & $\begin{array}{l}\text { Mental disorders } \\
\text { Immunity } \\
\text { Inflammation }\end{array}$ \\
\hline $\begin{array}{l}\text { Durkheim ( Suicide } \\
\text { Theory) }\end{array}$ & $\begin{array}{l}\text { Egoistic } \\
\text { Insufficient integration within a } \\
\text { specific group } \\
\text { Anomic } \\
\text { Lack of social regulation, an } \\
\text { unexpected amount of stress, and } \\
\text { frustration. } \\
\text { Altruistic } \\
\text { High social involvement } \\
\text { Fatalistic } \\
\text { Extreme social regulations and } \\
\text { expectations }\end{array}$ & $\begin{array}{l}\text { Quarantine, } \\
\text { Social distancing } \\
\text { Financial loss } \\
\text { For unemployment } \\
\text { Loss of loved ones } \\
\text { Self-sacrifice } \\
\text { A new concept of distancing, } \\
\text { Lockdown, } \\
\text { Lack of social rituals }\end{array}$ \\
\hline
\end{tabular}


DOI: https://doi.org/10.47405/mjssh.v6i10.1071

\section{Joiner's Interpersonal Theory (Jr, Kimberly \\ A, K., \& David, 2009) Three-step Theory}

Lack of reciprocation and perceived burdensomeness Hopelessness and mental illness
Changed in social reciprocation

The panic situation during the period of lockdown, Uncertainty unemplovment

The table shows major theories that are related to mental health including social stress theory, biological theories, Durkheim's suicide theory, Joiner's interpersonal theory, and three-step theory to explain the causes of mental health conditions among young ages in Bangladesh.

\section{Results}

\section{Socio-demographic Condition of Male and Female}

The information of the study was constructed by the researchers from the young male and female (aged 20-25) of Jamalpur district and these respondents are suffering from different types of mental health issues. At the starting of each case study, socio-demographic data were gathered from each participant concerning their age, religion, and educational qualification, marital status, family income (monthly). The information of respondents has been accumulated to analyze the in-depth conditions of respondents from the Bangladesh point of view.

Table-2: Socio-demographic profile of Male

\begin{tabular}{llllll}
\hline $\begin{array}{l}\text { Case Study } \\
\text { No }\end{array}$ & Age & Religion & $\begin{array}{l}\text { Educational } \\
\text { Qualification }\end{array}$ & Marital Status & $\begin{array}{l}\text { Family Income } \\
\text { (Monthly) }\end{array}$ \\
\hline C.S no-1 & 21 & Muslim & Under Graduation & Unmarried & 60,000 \\
C.S no-2 & 23 & Hindu & Graduation & Unmarried & 40,000 \\
C.S no-3 & 22 & Muslim & Under Graduation & Unmarried & 30,000 \\
C.S no-4 & 25 & Muslim & $\begin{array}{l}\text { Under Post- } \\
\text { Graduation }\end{array}$ & Married & 80,000 \\
C.S no-5 & 22 & Muslim & Under Graduation & Unmarried & $1,20,000$ \\
C.S no-6 & 21 & Hindu & Under Graduation & Unmarried & 25,000 \\
C.S no-7 & 23 & Hindu & Graduation & Married & 70,000 \\
C.S no-8 & 20 & Muslim & Under Graduation & Unmarried & 15,000 \\
C.S no-9 & 24 & Muslim & Graduation & Unmarried & 50,000 \\
C.S no-10 & 22 & Muslim & Under Graduation & Unmarried & 20,000 \\
\hline
\end{tabular}

Note: $\mathrm{CS}=$ Case Study

The table shows the socio-demographic profile of males who are the students of under graduation, graduate, and post-graduation level in different educational institutions. They have come home from their educational institution due to COVID-19 issues. According to the age distribution, all the respondents are aged between 20-25 years old. Bangladesh is a Muslim country, most of the respondents are Muslim, but there are three Hindus also. Maximum male respondents are unmarried and only two are married. The family income of six respondents is between 15,000-50,000 taka per month and four respondent's income ranges 70,000-120,000 taka. Remarkable diversity can appear that relatively married respondent's families earn more money than unmarried people. Most of the young people of Bangladesh are dependent on their family income before completing their graduation. Although many do part-time jobs or tuition, there is no certainty of that. Uncertain income can bring unhappiness between spouses unless there is financial support from the family. 
Table-3: Socio-demographic profile of Female

\begin{tabular}{|c|c|c|c|c|c|}
\hline $\begin{array}{l}\text { Case Study } \\
\text { No }\end{array}$ & Age & Religion & $\begin{array}{l}\text { Educational } \\
\text { Qualification }\end{array}$ & Marital Status & $\begin{array}{l}\text { Family Income } \\
\text { (Monthly) }\end{array}$ \\
\hline C.S no-1 & 20 & Muslim & Under Graduation & Married & 50,000 \\
\hline C.S no-2 & 22 & Muslim & Under Graduation & Unmarried & 40,000 \\
\hline C.S no-3 & 24 & Hindu & Graduation & Married & 38,000 \\
\hline C.S no-4 & 21 & Muslim & Under Graduation & Unmarried & 90,000 \\
\hline C.S no-5 & 21 & Hindu & Under Graduation & Unmarried & 20,000 \\
\hline C.S no-6 & 25 & Muslim & $\begin{array}{l}\text { Under Post- } \\
\text { Graduation }\end{array}$ & Married & 50,000 \\
\hline C.S no-7 & 20 & Muslim & Under Graduation & Unmarried & 25,000 \\
\hline C.S no-8 & 20 & Muslim & Under Graduation & Unmarried & 20,000 \\
\hline C.S no-9 & 21 & Hindu & Under Graduation & Married & 70,000 \\
\hline C.S no-10 & 22 & Muslim & Under Graduation & Unmarried & 80,000 \\
\hline
\end{tabular}

Note: $\mathrm{CS}=$ Case Study

The table shows the socio-demographic profile of females in different institutions where they are studying under graduation, graduation and, post-graduation. Eight young women are under graduation level, one is graduation and another is under post-graduation level. Researchers have taken ten female respondents and all of them are aged 20-25 years. The table indicates that four females entered married life and six are unmarried. Of the four married people, three have recently got married during the period of COVID-19. Most of the parents in Bangladesh want their daughters to get married at the under-graduation level and they think that if their daughter is older it will be a problem to get married after finishing their post-graduation. The family income of seven respondents ranges between 20,00050,000 taka per month and three respondents is 60,000-90,000 taka. This study shows that financially weak parents want their daughters to get married early. Although the thinking of parents is changing in the present era and many parents want their daughter to be self-reliant and do something for the family. Not only that sometimes people of in-law's house also support their undergraduate bride and they think that she can increase social status for their future generation.

\section{Critical situations faced by young adults and its impact on Mental Health during COVID-19}

\section{Financial Hardship}

Bangladesh is one of the developing countries in the world where most people work hard to maintain their livelihoods. This study shows that many young educated people bear their educational expenses as well as family expenses. They used to do tuition and took care of their parents also. During the period of COVID-19, they lost their tuition. For this reason, they are suffering from an extreme financial crisis. Some young people are involved in part-time jobs, but they also lost their job. Another respondent expressed his worst experience. He told that:
Before the pandemic, I used to do four tuitions and earned a lot of money every month. During the period of Covid-19, I lost all the tuition within the same month. I am facing a lot of financial crises because I didn't have any savings. I also used to help my family maintaining all the expenses in households because of only earning members of my family. Since I had no source of income, I started extorting money from many of my solvent friends. However, they have stopped lending due to their economic problem.

Financial hardship affects badly on their mental health. In 2020, people all over the world celebrated World Mental Health Day during a period of crucial time. The theme is that people should improve their mental health by increasing psychological support. For the COVID-19 pandemic situation, young people explored self-isolation, quarantine, break of education, and another crisis (Huda, 2020). In the 
World Economic Forum report 2018, one in four people were affected by mental health problems (For example, anxiety, depression, stress, and mental disorders, etc.) in their lives. This study observes that for the pandemic situation, young mental illnesses are increasing.

Figure 4: Mental Health condition

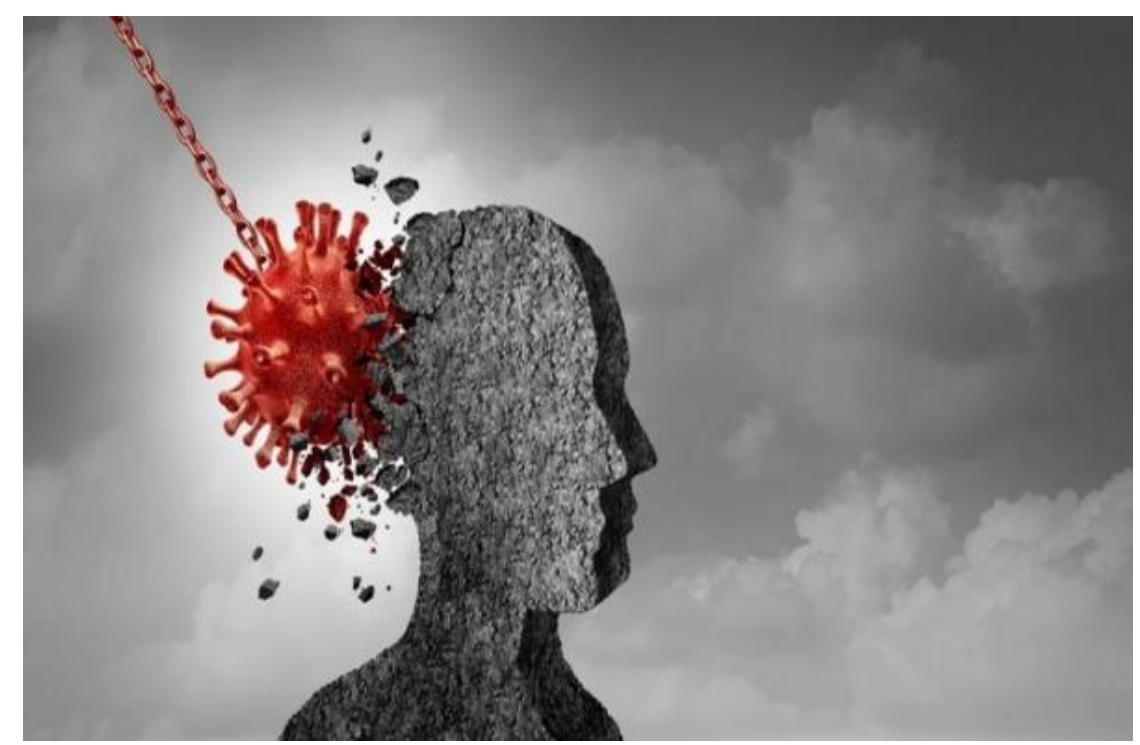

The National Mental Health Survey in Bangladesh from 2018-19 reported that around 17 percent of Bangladeshi young are undergoing mental health problems like depression, anxiety, stress, and obsessive-compulsive disorders. This study portrays that educated Young people are suffering from mental health issues because they have the pressure to establish in their life and they want to be stable financially. Because of economic hardship, many students are forced to work on the land. And the possibility of their dropping out from educational institutions has been created that affect diversely on their mental health. One respondent shared his mental health issues. He cited that:

I have completed my graduation from a well-known University and now I am a student of the post-graduation level. I have been away from studies for fourteen months, but this was the appropriate time to prepare myself. But unfortunately, I didn't get the opportunity to read and I have to work with my father in another land. With all this, I am mentally broken. My parents have high expectations for me, but unfortunately, I think I failed to fulfill their dreams. I am fighting with my mind about what I should do.

\section{Conflict with Family Member}

Young people like to spend their time with family, but 24 hours a day is very stressful when they are facing many problems such as the economic crisis and virus-related mental pressure (Red Cross Australian). The study demonstrates that young ages get into quarrels with family members over small issues because they stay home all day. Young people think that as a result of staying at home all day, the family members get in trouble with them and they are the cause of annoyance. Parents give pressure on young people to concentrate on study and order them to stay away from the phone. Not only that there is always a quarrel with family over many other issues. One respondent shared her opinion:

Since my University is closed I spend more time on the internet than the previous time. Most of the time, I also do classes on the internet, but my parents scold me whenever they see me on the phone. I have disagreed with them in other matters as well. The relationship with family became very bitter as stayed at home for a long time. 
There is a noticeable issue in the study is that despite conflict with family, there are some positive effects that can make family bonding stronger. Because people get more time to spend their quality time with family member together. During the period of COVID-19, all the members of the family watch movie, cook different delicious food, play indoor games, develop their skills by a different kind of training program, etc. which is helpful to remove their depression, anger, anxiety, etc. One respondent described that:

From the beginning of COVID-19, I spend 24/7 with my family members and it was a wonderful experience for me. Most of the offices are opening, though the University has not opened yet. Now I think that when the educational institutions will open, I will miss my family a lot. COVID-19 teaches me how important the family is! I was infected by COVID-19 and my family was with me during that crisis period. I am blessed that Almighty Allah gives me such a beautiful family in my life.

\section{Quarantine Related Crisis}

Coronavirus has spread across the world and quarantine and sheltering are essential issues for maintaining distance, most importantly it is a big impediment for third-world developing countries like us (Openshaw \& Travassos, 2020). COVID-19 related pandemic effects on youth mental health. The study shows that due to quarantine young are facing some mental hazards include low mood, depression, anger, insomnia, suicide tendency, loneliness anxiety, and so on. Another crisis of quarantine is that youth people are involved in risk zone spending more time on the internet which harms their minds. Some young are being habituated to search prohibited and age-restricted sites due to lazy brains. One of the respondents expressed his opinion.

When I was at home during the period of the corona, I felt very lonely and I was very much depressed. That time I searched different types of interesting pornography sites and this reduced my loneliness. After some days later, I was addicted to pornography a lot. I got all kinds of happiness from it. Now I realize that it is a very bad habit and I want to get back from it.

\section{Increasing Pressure for Marriage}

As the poorest country, COVID-19 is already having devastating on youth mental health as well as economies and families. COVID-19 affects both young boys and girls. Young girls are becoming victims of forced marriage day by day. Nowadays girls have acquired the ability to survive in competition with boys. However, due to COVID-19 Young girls are encountering different types of pressures not only from their core families but also from the neighbors, relatives, and overall by the society that may hinder their future social development. Marriage pressure for young girls is acute than any other pressure. Some young women who are involved in a love affair with same-age relationship are mentally devastated by the pressure of their parents about marriage. Some of the respondents are facing this kind of problem. One of them shared that:

When I was in my second year, I was involved in a relationship with my friend and it is continuing. Our commitment is strong. When I came to my home during the period of COVID-19, my parents gave me pressure for marriage. I can't share with my family member about my lover because he is also a student and it will take time to establish himself. We were dedicated to our relationship. But, the Pandemic ruined everything. My parents put a lot of mental pressure on me to get married that was unavoidable. Eventually, I was forced to get married and bound to sacrifice my love relationship. 


\section{Addiction to the virtual world and video games}

COVID-19 has forced young people for staying home and closed educational institutions for a long time. For this reason, it creates a disaster in the life of young people in Bangladesh. For the accessibility of the internet or smart devices and sufficient time, some young people are addicted to the virtual world and video games, for example, addiction to playing free fire and PUBG mobile game which makes the young people unproductive and it hampers the physical health of the youth (Hossen, 2020). These types of addiction engulf youth's future. One respondent expressed:

I stayed at home because University was closed for a long time and I was very much upset with my life. That time I started free-fire PUBG and it brought me ultimate happiness. The game started at night and continued till morning. Then I would go to sleep and slept all day. Recently, I realized that I am getting addicted adversely. Not only that, for the lack of proper sleep, I cannot remember many things and my anger has increased a lot.

\section{Deterioration of mental health of youth}

Young people in pandemic situations are going through a lot of psychological issues like sadness, worry, fear, anger, annoyance, frustration, guilt, helplessness, loneliness, and nervousness which make them commit suicide (Bhuiyan, Sakib, Pakpour, Griffiths, \& Mamun, 2020). This study observed suicide tendency is associated with severe psychological morbidities-loneliness, anxiety, depression, low self-confidence, psychological trauma, and so on. Therefore, several risk factors have the contribution to deteriorate the mental condition of young people during the period of the pandemic that is summarized below:

Table-4: Mental Health Conditions and Contributors during the period of COVID-19

\begin{tabular}{ll}
\hline $\begin{array}{l}\text { Mental Health conditions during } \\
\text { COVID-19 }\end{array}$ & \multicolumn{1}{c}{ Contributors } \\
\hline Psychological disorder & Depression \\
& Stress \\
& Anxiety \\
& Post-traumatic disorder \\
Isolation and Loneliness & Quarantine \\
& Social distance \\
& Travel restriction \\
Uncertainty & Misinformation \\
& New nature of the infection \\
Young vulnerabilities & Insufficient Vaccine \\
& Access use of internet \\
& Drug addiction \\
Economic uncertainty & Alienated from family member \\
& Financial crisis \\
& Increasing unemployment \\
& Salary loss \\
& Reducing the opportunity of work \\
\hline
\end{tabular}

The table depicts the respondent's opinions about causes for mental conditions and contributors during the period of the COVID-19 pandemic. There are some major psychological statuses including psychological disorder, isolation and loneliness, uncertainty, young vulnerabilities, and economic uncertainty that are faced by young people during this time. These conditions have also several contributors that are prone to commit suicide as well as deteriorate the overall mental conditions. During the pandemic, some young people are going through depression, stress, anxiety, and so on that causes psychological conflict. They are unable to take the right decision holding such psychological conditions that turn into suicide. Different measures: as flight bans, mandatory lockdowns-shutting 
down educational institutions, and social distancing- at least 6 feet are forced to apply to prevent the own society from spreading coronavirus disease (Mahmud, 2020). One respondent opined that,

Such lockdowns are constantly capturing people both physically and mentally who have to maintain social distance policy and are unable to visit recreational places for entertainment. Therefore, people are experiencing loneliness, anxiety, depression, and lack of self-esteem, which are throwing them into psychological trauma.

Forced quarantine, social distance, travel restrictions, etc. are somehow contributing to preventing COVID-19 from getting infected; however, they are also responsible to create isolation and loneliness especially among young who are continuously used to engage social activities. Otherwise, there is also some misinformation about the virus, insufficient vaccine, and also changing nature of the virus creates uncertainty among people. Young ages are confused about their future that sometimes lose their hopes and tend to commit suicide. In the time of COVID-19 young are constantly engaging with drug addiction through the excessive use of the internet and also for alienation from the family member. Due to their excessive internet use, they are less interactive with their family members that create conflict with each other in the family. Sometimes conflicting situations in the family are responsible to influence suicidal attempts. Unhealthy use of technology cannot replace human interaction and it creates complex situations among young people (Banerjee, Kosagisharaf,\& Rao, 2020). One of the respondents expressed his opinion. One day he tried to commit suicide. He said,

During the period of COVID-19, I came to my hometown from my University hall. That time I thought that I will enjoy this time like a vacation. But some days later, I was too much depressed with my life, I could not tolerate this lifestyle and sometimes I used to quarrel and beat my siblings without a specific reason and I used to habituate in smoke that time. I could not find any purpose in my life. One night I went to commit suicide, but my brother saved me. Then I took counseling and medicine on the advice of the doctor. Now I am on the way to getting well.

According to respondents, because of the coronavirus, many people have lost their jobs and their salaries have dropped dramatically. For this low pay and unemployment, there is a kind of economic uncertainty in the family's breadwinner. Even those who have lost their jobs can't find a job because of reducing the opportunity of work during the COVID-19 situation. According to them, they have no choice but to commit suicide. One respondent shared that,

My father used to work in a private company. Because of the coronavirus impact, the company initially cut salaries, then Baba (His father) somehow started running the family. The later company began firing those who were growing older. After leaving the job, my father was devastated. Baba used to go out every day in search of work. However, fortune didn't work out badly. Then, my father took us from our house where we lived in the city to our village. I couldn't adapt to the new place. I was completely alienated from my friends. My parents and siblings always worried for me. I thought that if I left the world, maybe their thoughts for me would go away. So I decided to commit suicide. With the cooperation of family members, I have now started a new agricultural project in my village in Jamalpur district which is inspiring me as well as my family to live a new way.

\section{Discussion and Theoretical implications}

The study addressed remarkable diversity in terms of socio-demographic perspective. During the pandemic situation, though some young people did part-time jobs or tuition, their jobs are now uncertain that brings unhappiness between married couples along with other family members. Young ages get into quarrels with family members because they stay home all day. Parents give pressure on young people to concentrate on study and order them to stay away from the phone. There is the 
noticeable issue in the study is that despite conflict with family, there are some positive effects of spending quality time with family members together. During the period of Covid-19, some young ages watch the movie, cook different delicious food, play the indoor game, develop their skill by different kinds of training programs, etc. with their family members which can make family bonding stronger.

Furthermore, young girls are becoming victims of forced marriage due to COVID-19 not only by their core families but also by their neighbors, relatives, and overall by the society that may hinder their future social development. Another crisis in the time of pandemic is that youth ages are being habituated to search prohibited and age-restricted sites on the internet due to quarantine, lockdown, and shutdown periods. For the accessibility of the internet or smart devices and sufficient time, some young people are addicted to the virtual world and video games, for example, addiction to playing free fire and PUBG mobile games that may engulf youth's future.

There are some major psychological conditions including psychological disorder, isolation and loneliness, uncertainty, young vulnerabilities, and economic uncertainty that are faced by young ages during this time. During the pandemic, some young people are going through depression, stress, anxiety, and other contributors that cause psychological conflict. Forced quarantine, social distance, travel restrictions, etc. are also responsible to create isolation and loneliness especially among the young. Otherwise, there is also some misinformation about the viruses, insufficient vaccine, and also changing nature of virus creates uncertainty among young for future. In the time of COVID-19 young are constantly engaging with drug addiction due to excessive use of the internet and also for alienation from the family member.

Otherwise, because of the coronavirus, many people have lost their jobs and their salaries have dropped dramatically. For this low pay and unemployment, there is a kind of economic uncertainty in the family's breadwinner. Even those who have lost their jobs can't find a job because of reducing the opportunity of work during the COVID-19 situation. According to them, they have no choice but to commit suicide or facing other psychological trauma. Young people are affected by mental health problems include depression, loneliness, anxiety, anger, stress, and so on. Therefore, due to the pandemic, young are recognizing deficiencies themselves in terms of social integration that is linked to Rubinstein's social stress theory of Suicide (1986). From the point of Durkheim's Suicide theory, the study shows that quarantine, social distance, financial crisis, unemployment, broken heart of lovers, lockdown, lack of social ritual as well as social activities create insufficient integration within a social group and also create low social regulations, an unexpected amount of stress, and frustration that turns into egoistic and anomie tendency of young ages. Therefore, according to the three-step theory, the panic situations during the period of lockdown, uncertainty, unemployment create hopelessness and mental illness.

\section{Limitations and Recommendations}

Young people are at greater risk of COVID-19 not only physically but also mentally which is an unconcern. Most of the time, young don't share their problems with others and consequently, risky for their mental health. Here, the study has explored the main objective of the research: the COVID-19 pandemic and its effect on youth mental health in Bangladesh. The remarkable variations have been also observed in the study in terms of the socio-demographic status, and multidimensional perceptions about critical situations faced by young adults and their impact on Mental Health during COVID-19. The study is not beyond limitations. One of the limitations is that the study of the sample was limited and all the respondents have been chosen from Jamalpur district purposively. For this reason, researchers can fail to measure the complete picture of the research. Another limitation of this research is that respondents may give inappropriate information about themselves which is not possible to verify. Despite these limitations, the result of the present study has considerable importance as well as the findings may provide a cornerstone for doing further study in these research issues.

Almost 92\% did not seek mental health services due to stigma, negative perceptions, inadequate knowledge, misconceptions about treatment, and treatment cost (National Mental Health Survey, 
Bangladesh 2018-2019). The study has tried to show the mental health condition of young males and females and how COVID-19 affects their mental health, and address to seek mental health services. Not only that the following recommendations may be helpful to prevent such kind of hazardous mental conditions faced by young ages during the pandemic.

To reduce the risk of COVID-19, the mandatory task for young people to follow preventive measures: clean hand with soap, cover nose and mouth when coughing, wearing the mask, avoid close contact with others when you are experiencing a cough, and fever, avoid unprotected contact with wild animals. They can also involve developing social consciousness among common people that may be helpful to reduce their mental pressure also. There is a needed arrangement for counseling for young people to improve their mental health conditions. Proper counseling can reduce the suicide rate of young people.

Sociologists, psychologists, social workers can arrange COVID-19 based consciousness-raising program online for young people where the negative aspects of mental health will be described and suggested how to come back from it. Young people have to be patient in their pandemic situations. An online business can be done from home to overcome the financial crisis. They need to convince themselves that the situation will be changed one day. Already Bangladesh government has been taken many steps for all the people. But the government should be more concerned about the mental health of young people because youth are the future of the nation. Although vaccination activities already started, everyone needs to be vaccinated as early as possible.

\section{Conclusion}

The research has tried to investigate the relationship between the COVID-19 pandemic with its effects on mental health among young ages in Bangladesh. Young adults are facing critical situational conditions such as acute economic hardship, constant conflict with family members, a hazardous mental condition during quarantine, growing pressure for marriage especially young girls, increasing addiction to the internet and virtual world, and so on. For this situational unfavorable condition young ages are suffering several psychological crises including suicidal tendency, hopelessness, loneliness, anxiety, depression, low self-confidence, and overall psychological trauma in their life. Among all these critical mental conditions, the suicidal tendency is acute among the young generation. However, some young have recognized COVID-19 not only as a curse but also as a blessing in the sense that they got time to enjoy quality time with family members after a long time which enhances their family bonding. Mental health conditions are not considered seriously by our society, however, they should be. Therefore, young ages need to be strong mentally to cope with the pandemic and should be influential for society.

\section{References}

(n.d.). Retrieved 02 12, 2021, from Red Cross Australian: https://www.redcross.org.au/stories/covid19/covid-19-and-family-conflict

Aresfin, N., \& Shafiullah, M. (2020, 11 17). Retrieved 02 13, 2021, from The Financial Express: https://thefinancialexpress.com.bd/views/views/childrens-mental-health-and-well-being-duringthe-covid-19-1602947561

Banerjee, D., Kosagisharaf,, J. R., \& Rao, T. S. (2020). 'The dual pandemic' of suicide and COVID19: A biopsychosocial narrative of risks and prevention. Elsevier Public Health Emergency Collection .

Bhuiyan, A. K., Sakib, N., Pakpour, A. H., Griffiths, M. D., \& Mamun, M. A. (2020). COVID-19Related Suicides in Bangladesh Due to Lockdown and Economic Factors: Case Study Evidence from Media Reports. International Journal of Mental Health , 1-6. 
Courtney, D., Watson, P., Battaglia, M., Mulsant, B., \& Szatmari, P. (2020). COVID-19 Impacts on Child and Youth Anxiety and Depression: Challenges and Opportunities. The Canadian Journal of Psychiatry, 65 (10), 644-691.

deCatanzaro, D. (1980). Human suicide: a biological perspective. Behavioral and Brain Sciences , 3 (2), 265-272.

Fegert, J. M., Vitiello, B., Plener, P. L., \& Clemens, V. (2020). Challenges and burden of the Coronavirus 2019 (COVID-19) pandemic for child and adolescent mental health: A narrative review to highlight clinical and research needs in the acute phase and the long return to normality. Child and Adolescent Psychiatry and Mental Health, 1-14.

Haque, I. E., Haque, M., \& Muniruzzaman, M. (2020). Young Age and Crime in Society: A Study on Youth Prisoners in Bangladesh. International Journal of Social Science Studies , 8, 91.

Hossen, M. B. (2020, 08 29). Retrieved 06 20, 2021, from risingbd.com: https://www.risingbd.com/english/interview/news/73525

Huda, M. N. (2020, 10 10). Retrieved 02 11, 2021, from The Daily Star: https://www.thedailystar.net/opinion/news/mental-health-all-during-the-covid-19-pandemic1975269

Jr, J. T., Kimberly A, V. O., K., W. T., \& David, R. M. (2009). The Interpersonal Theory of Suicide: Guidance for Working With Suicidal Clients. American Psychological Association, 246.

Mahmud, F. (2020, March 20). Retrieved September 14, 2021, from Alzazeera: https://www.aljazeera.com/news/2020/3/20/coronavirus-in-dense-bangladesh-social-distancinga-tough-task

Maps \& Travel information of Bangladesh. (n.d.). Retrieved 02 11, 2021, from https://bdmaps.blogspot.com/2011/11/jamalpur-sadar-upazila.html

National Mental Health Survey, Bangladesh 2018-2019. (n.d.). Retrieved 09 02, 2021, from National Mental Health Survey, Bangladesh 2018-2019: https://hsd.gov.bd/site/photogallery/741f00515ef1-4ad2-8faf-2569002a5fe7/National--Mental-Health-Survey-bd-2018-2019

Openshaw, J. J., \& Travassos, M. (2020). COVID-19, Quarantines, Sheltering-in-Place, and Human Rights: The Developing Crisis. The American Journal of Tropical Medicine and Hygiene , 103 (2), 578 .

Rubinstein, \& H, D. (1986). A Stress-Diathesis Theory of Suicide. Suicide and Life-Threatening Behavior , 16 (2), 182.

Rubinstein, \& H, D. (1986). A Stress-Diathesis Theory of Suicide. Suicide and Life-Threatening Behavior; New York, 16 (2), 182.

Son, C., Hegde, S., Smith, A., Wang, X., \& Sasangohar, F. (2020). Effects of COVID-19 on College Students' Mental Health in the United States: Interview Survey Study. Journal of Medical Internet Research, 22.

WIKIPEDIA. (n.d.). Retrieved 02 11, 2021, from https://en.wikipedia.org/wiki/Jamalpur_District

World Economic Forum. (n.d.). Retrieved 09 02, 2021, from World Economic Forum: https://www.weforum.org/reports/the-future-of-jobs-report-2018

Worldometer. (2021, august 26). Retrieved august 26, 2021, from Worldometer: https://www.worldometers.info/coronavirus/country/bangladesh/

Zhou, h.-J., Zhang, L.-G., Wang,, L.-L., Guo, Z.-C., Wang, J.-Q., Chen, J.-C., et al. (2020). Prevalence and socio-demographic correlates of psychological health problems in Chinese adolescents during the outbreak of COVID-19. European Child \& Adolescent Psychiatry, 749-758. 